\title{
3: 50624207-50618930
}

National Cancer Institute

\section{Source}

National Cancer Institute. 3: 50624207-50618930. NCI Thesaurus. Code C41967.

Physical location of CISH_Gene 